\title{
"Dikomikin Saja" Digitalisasi Komik Pembelajaran Sejarah Perjuangan Bangsa Berbasis Android
}

\author{
(Upaya Meningkatkan Minat Dan Hasil Belajar Siswa Pada Pelajaran IPS \\ Materi Sejarah di SMP Negeri 3 Madang Suku I Mengunakan Aplikasi \\ Pembuatan Komik Digital berbasis Android)
}

\author{
Himawan Bastari \\ SMP N 3 Madang Suku I, Kec: Madang Suku I, Kab: OKU Timur Prop Sum-Sel \\ E-mail: himaone08@gmail.com
}

\begin{abstract}
Abstrak: Penelitian ini bertujuan untuk menguji kefektifitasan aplikasi "Dikomikin Saja" dalam meningkatkan minat dan hasil belajar pada mata pelajaran ilmu pengetahuan sosial (IPS) khususnya materi sejarah, serta mendeskripsikan bagaimana proses pembuatan dan penggunaan aplikasi "Dikomikin Saja". Penelitian ini dilaksanakan dalam beberapa 3 (Tiga) kali pertemuan, dalam prosesnya sebanyak 2 (dua) kali mengunakan media pembelajaran "Dikomikin Saja" dan 1 (Satu) kali tidak menggunakan media pembelajaran "Dikomikin Saja". Peneliti melaksanakan tiga kali pertemuan dalam penelitian ini, dalam tiga kali pertemuan tersebut peneliti mengambil data dan mengobservasi aktivitas siswa yang berjumlah 35 siswa, dari tiga pertemuan tersebut terdapat peningkatan keaktifan siswa dalam proses pembelajaran dari skor awal 2,13 predikat cukup pada pertemuan awal menjadi 3,25 pada pertemuan ke II/terakhir dengan predikat sangat baik, begitu pula dengan minat belajar sejarah lebih tinggi terlihat dari rekapitulasi ketuntasan belajar siswa pada pertemuan awal 40,54\% yang tuntas menjadi 68,08 \% yang tuntas pada pertemuan terakhir atau ke - II. Aplikasi "Dikomikin Saja" membantu siswa dalam meningkatkan minat dan hasil belajar khususnya pada mata pelajaran IPS materi sejarah, serta membantu siswa untuk memenuhi bacaan-bacaan sejarah yang lebih populer yang dihasilkan oleh mereka sendiri..
\end{abstract}

Kata Kunci: “Dikomikin Saja”, Komik Sejarah, Peningkatan hasil belajar

UTILITY: Jurnal IImiah Pendidikan dan Ekonomi

Permalink: https://journal.stkipnurulhuda.ac.id/index.php/utility/article/view/333

How to cite (APA): "Dikomikin Saja" Digitalisasi Komik Pembelajaran Sejarah Perjuangan Bangsa Berbasis Android. UTILITY: Jurnal Ilmiah Pendidikan Dan Ekonomi, 2(2), 98-110.

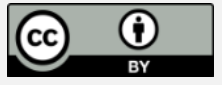

This is an open access article distributed under the terms of the Creative Commons Attribution 4.0 International License, which permits unrestricted use, distribution, and reproduction in any medium, provided the original work is properly cited. 


\author{
"Dikomikin Saja" \\ Digitalisasi Komik Pembelajaran Sejarah Perjuangan Bangsa Berbasis Android
}

\title{
PENDAHULUAN
}

Pendidikan hari ini merupakan proses pembentukan kader pembangunan bangsa, proses pendidikan diharapkan memberikan kontribusi kepada pribadi serta masyarakatnya dalam wujud kemampuan berpikir, menganalisis dan memecahkan masalah yang nantinya dapat dijadikan bekal membangun negeri dikemudian hari.

pendidikan merupakan proses pen-transformasi-an seluruh aspek kepribadian yang ada pada setiap individu manusia, didalamnya mencakup nilai dan sikap dan pengetahuan persis yang diutarakan oleh Sadulloh pendidikan merupakan proses transformasi nilai dari satu level generasi ke generasi selanjutnya, dengan proses transformasi nilai tersebut menjadikan generasi berikutnya memiliki bekal untuk membangun peradaban baru dengan warisan nilai nilai tadi (Sadulloh, 2012).

Salah satu cara pen-transformasi-an nilai tersebut adalah dengan pendidikan sejarah, menurut Kochhar (2008) pengajaran sejarah bukan saja mempelajari nilai nilai masa lampau, tetapi juga mempelajari nilai nilai keilmuan, pendidikan, etika, budaya, politik, nasionalsme, internasionalisme, kerja, dan kependidikan yang berlaku saat ini serta beberapa informasi lainya, karena nilai yang diajarkan pada pendidikan sejarah maka siswa dapat mempelajari nilai nilai masa lampau untuk dijadikan pelajaran menyongsong masa depan, pada tingkat SMP pembelajaran sejarah sudah terfokus kepada proses pensadaran akan sebuah peristiwa sejarah bukan lagi penghafalan fakta sejarah yang berupa menulis,mengingat,dan menghafalkan.

Proses pembelajaran sejarah yang terintegrasi pada pelajaran IPS terpadu memiliki posisi yang strategis untuk pembentukan karakter dan pewarisan nilai nilai kebangsaan dan bermuara pada rasa cinta tanah air serta bangsanya, pentingnya pelajaran sejarah saat ini kurang dipahami secara utuh oleh peserta didik dan masyarakat mereka masih beranggapan bahwa sejarah merupakan sebuah peristiwa yang hanya dicatat, diingat, dihapal dan kemudian dijawab pada selembar kertas ujian, pada sisi lain materi sejarah dalam bentuk teks buku juga terkesan berat serta menjemukan sehingga para peserta didik memiliki keengganan untuk mempelajarinya.

Prof. Hamid Hasan (2012), memaparkan ketidakminatan peserta didik terhadap pendidikan IPS khususnya materi sejarah karena model pengajaran sejarah yang jauh dari harapan sepi peminat serta ketidak mampuan pendidik 
untuk melihat hubungan antara sejarah masa lampau dengan kehidupan masa kini dan masa depan. Selain faktor diatas peserta didik juga kurang menyukai membaca teks pelajaran sejarah, mereka lebih menyukai bahan bacaan yang bergenre popular, bergambar dan ditambah lagi dengan penguasaan para guru/tenaga pengajar pada pelajaran IPS khususnya materi sejarah sangat minim dan kurang, hal ini disebabkan guru/tenaga pendidik bukan merupakan produk jurusan sejarah sebagian besar guru IPS merupakan produk lulusan ekonomi, geografi dan sosiologi, hal ini menyebabkan ketika mengajar materi sejarah tidak maksimal dalam penyampaian dan akhirnya bermuara pada tidak tercapainya tujuan pembelajaran, permasalahan tersebut menyebabkan ketidak minatan para siswa semakin besar terhadap pelajaran IPS khususnya pada materi sejarah.

Mengajarkan materi sejarah pada ilmu pengetahuan sosial pada pendidikan dasar dibutuhkan stimulan dan variasi pendekatan sehingga anak didik menjadi lebih aktif. Kasmadi (2001), "Stimulan yang dimaksud berupa media pembelajaran, konsep pembelajaran dan model pembelajaran yang dapat menarik perhatian siswa serta merangsang siswa agar lebih berkonsentrasi serta berminat untuk secara aktif terlibat dalam proses pembelajaran".

Model dan media yang digunakan pada pembelajaran IPS materi sejarah pada sekolah mengah pertama menurut Arsyad (2006) harus bisa membangkitkan keinginan dan minat baru, membangkitkan motivasi, merangsang kegiatan belajar serta memberikan pengaruh yang baik pada siswa.

Sedang menurut Arif S Sadirman (2012) media pembelajaran, “mencakup segala hal berupa alat fisik yang dapat menyajikan pesan, serta dapat merangsang siswa untuk belajar", penggunan media pembelajaran akan sangat membantu keefektifan proses pembelajaran serta penyampaian pesan dan tujuan pembelajaran.

Banyak media pembelajaran saat ini mengunakan, video dan CD Interaktif serta media lainya dengan harapan dapat membantu proses pembelajaran materi sejarah pada pelajaran IPS, tetapi penterlibatan anak didik pada media pembelajar diatas hanya sebatas objek saja tidak mengajak anak didik menjadi subjek yang membuat dan mengelola sendiri media pembelajaran tersebut, sekian banyak media pembelajaran baik video juga CD interaktif sebagaian besar memerlukan waktu untuk menayangkan atau memutarnya kadang kala disekolah tidak terdapat fasilitas pendukung dalam penggunaan media tersebut. 


\author{
"Dikomikin Saja" \\ Digitalisasi Komik Pembelajaran Sejarah Perjuangan Bangsa Berbasis Android
}

Salah satu media yang sangat tepat dipakai dengan keterbatasan yang ada adalah foto serta gambar yang disatukan dalam sebuah media berbasis komik, komik adalah media gambar yang mudah dibuat dengan bantuan aplikasi yang saat ini banyak kita jumpai dan memiliki keunggulan serta keunikan serta sangat familiar bagi peserta didik tentunya baik berbasis personal computer atau berbasis gawai android.

Menurut Sudjana dan Rivai (2011) "Media pembelajaran berbasis komik efektif digunakan pada proses belajar untuk meningkatkan minat, hasil serta apresiasi dalam pembelajaran."

Selain itu komik juga memilik beberapa kelebihan

a. Menarik dan umumnya semua orang senang melihat foto atau gambar.

b. Menyediakan gambar secara nyata

c. Memperjelas suatu peristiwa.

d. Mampu secara gamblang menceritan suatu kejadian secara berurutan.

Secara prinsip antara pelajaran IPS yang memuat materi sejarah dengan komik merupakan dua hal yang berbeda bahkan saling bertolak belakang, komik yang merupakan serangkaian gambar dan cerita, sedangkan materi sejarah merupakan mata pelajaran yang sebagian besar membahas momentum, pergerakan dan membahas masa lampau serta berisi teks panjang yang membosankan, jika materi materi sejarah dibuat dalam bentuk sebuah komik digital berbasis android dalam pembuatanya mengikutkan anak didik untuk membuat komik pembelajaran maka hal tersebut akan menjadi inovasi tersendiri dalam pembelajaran IPS, serta ketertarikan anak didik untuk berminat dan fokus pada mata pelajar IPS khususnya materi sejarah akan bertambah.

Untuk menjadikan inovasi media pembelajaran "dikomikin saja" lebih efektif dalam proses pembelajaran diperlukan model pembelajaran yang bisa mendukung, dari sekian banyak model pembelajaran, kooperatif menjadi tumpuan model pembelajaran, pada metode pembelajaran ini siswa diajak untuk lebih intens dan aktif dalam proses pembelajaran, selain itu juga siswa juga diberikan ruang gerak yang luas, demokratis sehingga kelas akan lebih berasa hidup serta hangat dan memberikan porsi yang besar kepada siswa dalam proses belajar. 
Pembelajaran kooperatif pada hakikatnya adalah kegiatan pembelajaran yang dilakukan oleh peserta didik dengan membentuk kelompok-kelompok dengan jumlah anggota tertentu. Menurut Gunarto (2013) kooperatif learning merupakan kegiatan berkelompok yang didalamnya terjalin kerjasama saling bantu membantu dalam pembelajaran. Lebih lanjut dijelaskan bahwa ciri khas dari pembelajaran kooperatif learning adalah terdapat interaksi antar anggota kelompok yang heterogen sehingga antar anggota tidak mendominasi dalam kegiatan pembelajaran

\section{METODE}

Penelitain yang dilaksanakan pada tahun 2018 dan merupakan Penelitaian Tindakan Kelas (PTK) yang dilaksanakan untuk menguji keefektifitasan penggunaan media pembelajaran "Dikomikin Saja" pada pelajaran IPS kelas VIII di SMP Negeri 3 Madang Suku I.

Jumlah subjek penelitian sebanyak 35 peserta didik, dengan metode pengumpulan data berupa observasi dan tes.

Pengolahan dan analisis data yang dipergunakan dalam penelitian ini adalah analisis deskriptif kualitatif dengan kerangka analisis sebagai berikut:

1. Seleksi data, pengelompokkan dan pengolahan data, dan interpretasi data

2. Evaluasi dan refleksi terhadap hasil interpretasi data

3. Tindak lanjut atau rekomendasi.

Kerangka pengolahan dan analisis data tersebut di atas akan diberlakukan pada setiap siklus tindakan sampai penelitian dianggap selesai. Khusus berkenaan dengan analisis data hasil penelitian meliputi:

1. Analisis, refleksi, dan tindak lanjut terhadap data hasil orientasi dan identifikasi masalah

2. Analisis, refleksi, dan tindak lanjut terhadap data perencanaan tindakan penelitian

3. Analisis, refleksi, dan tindak lanjut terhadap data hasil pelaksanaan tindakan penelitian

4. Pembahasan terhadap hasil dan temuan penelitian tindakan

5. Kesimpulan dan rekomendasi 


\section{A. Proses Penemuan dan Pembaharuan.}

Inovasi yang dikembangkan adalah aplikasi android yang berisi aplikasi aplikasi pembuatan komik digital serta aplikasi pembuatan buku digital yang digabungkan dalam satu aplikasi android yang dinamai "Dikomikin Saja" (Digitalisasi Komik Pembelajaran Sejarah Berbasis Android).

Dengan bagan alur sebagai berikut:

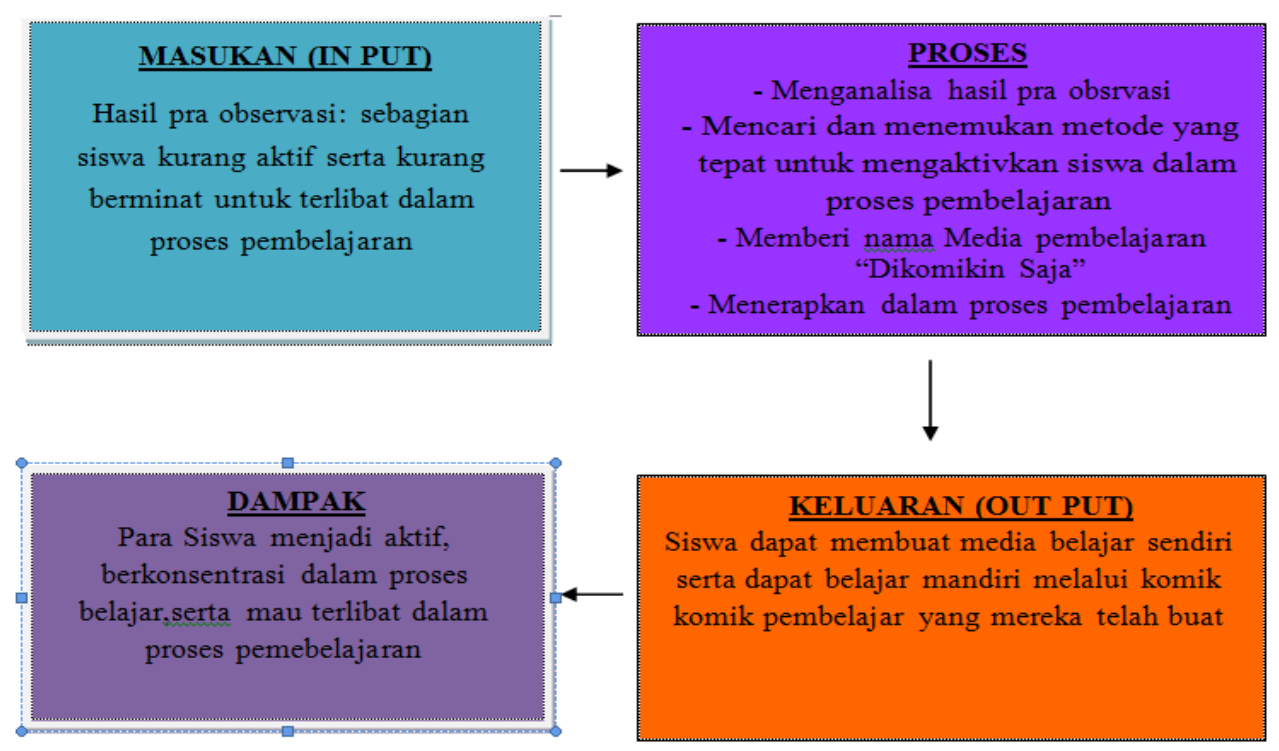

Gambar 1. Bagan Alur Penemuan dan Pembaharuan

Berikut ini kami deskripsiskan proses perancangan aplikasi "Dikomikin Saja" berbasis android.

\section{Pembuatan Aplikasi "Dikomikin Saja"}

Aplikasi ini sengaja di buat untuk mempermudah peserta didik serta guru untuk membuat komik pembelajaran IPS khususnya materi Sejarah dalam sebuah aplikasi yang mudah dan gampang digunakan.

2. Pembuatan aplikasi ini menggunakan personal Computer dengan bantuan aplikasi pihak ketiga APPY PIE.

Mengapa mengunakan pihak ketiga, hal ini disebabkan terbatasnya kemampuan guru dalam peng kodingan atau pemograman untuk membuat 


\section{Himawan Bastari}

aplikasi android, serta untuk memudahkan pihak lain untuk bisa mengembangkan aplikasi tersebut.

Dalam aplikasi android yang di buat berisi link-link untuk menjangkau program-program lain yang nantinya menjadi program dasar dalam pembuatan aplikasi ini. Link tersebut antara lain aplikasi android Comicize dan Steeler co.

3. Rilis Aplikasi "Dikomikin Saja"

Setelah Aplikasi "Dikomikin Saja" berhasil di buat maka langkah selanjutnya adalah mensebar luaskan kepada pengguna baik peserta didik maupun guru, aplikasi "Dikomikin Saja" bisa didapat dengan berbagai cara, mengunduh langsung pada aplikasi penyedia yaitu Appy Pie, Google Play Store, atau bisa juga dengan menyebarkan secara manual menggunakan aplikasi Share it.

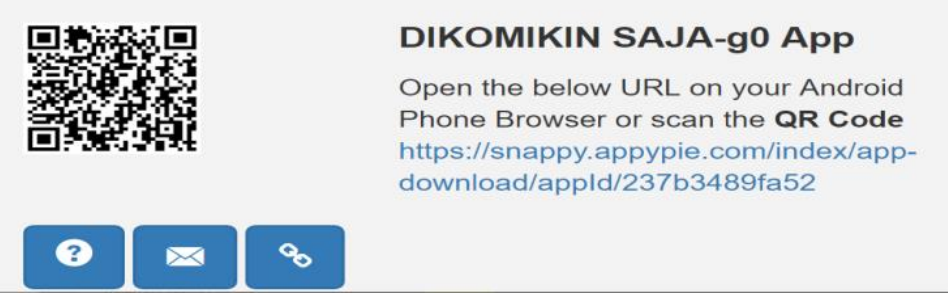

Gambar 2. URL . Dikomikin saja

\section{Oprasional Penggunaan Aplikasi "Dikomikin Saja"}

Aplikasi yang telah diinstal pada android dapat digunakan secara langsung karena didalam apalikasi tersebut telah terdapat penjelasan penggunakan aplikasi tersebut, didalam aplikasi tersebut terdapat 5 (Lima) alat/menu yang dapat digunakan untuk mengoprasikan aplikasi tersebut antara lain.

- Selamat Datang

Dalam alat/menu tersebut berisi penjelasan singkat dari kegunaan aplikasi "Dikomikin Saja" bagi proses pembelajar

- Syarat dan Ketentuan

Dalam alat/menu ini berisi tentang bagaimana penggunaan aplikasi "Dikomikin Saja" Dimulai dari cara menggunakan, cara menginstall aplikasi pendukung,sampai bagai mana membuat komik pembelajaran. 


\author{
"Dikomikin Saja" \\ Digitalisasi Komik Pembelajaran Sejarah Perjuangan Bangsa Berbasis Android
}

- Praktek “dikomikin Saja “

Praktek disini dimaksudkan sebagai alat/menu membuat komik itu sendiri cukup dengan menekan tombol/menu mulai membuat komik maka siswa atau guru dapat langsung mempraktekkan pembuatan komik pembelajaran digital mengunakan android

- Comicize

Pada alat/menu ini android akan tersambung langsung pada penyedia layanan pihak ketiga yaitu comicize.

- $\quad$ Steeler Co

Pada alat ini android akan tersambung langsung pada penyedia layanan pihak ketiga yaitu dengan menggunakan aplikasi android sebagai alat belajar menjadikan siswa aktif berkonsentrasi dalam proses belajar, memiliki rasa keingintahuan yang tinggi serta mulai tertantang untuk mencoba media pembelajaran tersebut.

Adapun langkah-langkah pembelajaran dengan menggunakan aplikasi "dikomikin Saja" tersebut adalah sebagai berikut.

1. Guru membagi peserta didik menjadi beberapa kelompok dengan jumlah tiap kelompok sebanyak tiga orang peserta didik. Pembagian kelompok dengan mempertimbangkan aspek heterogenitas.

2. Guru memberikan storyboard yang berisi naskah cerita yang harus diterjemahkan dalam bentuk komik oleh setiap kelompok.

3. Peserta didik berbagi peran dalam kelompok, yakni satu orang menjadi ketua sekaligus oprator serta dua orang peserta didik lainya menjadi sumber dan pengolah

4. Sumber dan pengolah mengumpulkan dan meramu informasi yang dibutuhkan baik berupa gambar foto yang bisa didapatkan dalam perambahan di dunia maya

5. Sedangkan oprator atau ketua mencoba merangkaikan antara gambar, foto atau yang lainya dengan pertimbangan dan informasi dari kedua sumber dan pengolah. 
6. Setelah semua informasi gambar dan foto dirangkaikan, koordinator kelompok bersama anggotanya menelaah dan menginterprestasikan rangkaian gambar tersebut secara bersama-sama.

7. Pada tahap akhir, hasil interpertasi gambar foto dan komik yang sudah dirangkai dengan mengunakan program comicize yang ada dalam program "dikomikin Saja "akan di publikasikan menjadi bentuk $e$ book dengan mengunakan aplikasi steeler Co yang juga sudah ada dalam program "dikomikin Saja “

8. Setelah semua sudah ter-publikasikan maka siswa mempresentasikan hasil karya mereka kepada teman lain, serta memposting hasil karyanya pada media sosial yang mereka miliki.

Rekam jejak kegiatan pembelajaran dari Penerapan media "dikomikin saja" pertama dilakukan pada tanggal tanggal 6 Maret 2018 (pertemuan awal) pada kelas VIII SMP Negeri 3 Madang suku I sedang pada tanggal 13 Maret 2018 pertemuan I (satu), sedangkan pertemuan ke II (dua) 20 april 2018, Pada pertemuan awal, I, dan II dengan pokok bahasan kedatangan bangsa eropa serta perlawanan bangsa Indonesia, dengan skenario pembelajaran sebagai berikut.

Pada pertemuan awal guru menyampaikan inti dari materi serta kompetensi yang akan dicapai, sebagai pengayaan awal guru memberikan sebuah cerita perjuangan rakyat aceh dalam perjuanganya mengusir penjajah, serta memberikan profil sosok pahlawan dari tanah aceh dalam bentuk slide profil kepahlawanan, setelah memamaparkan materi awal guru membagi siswa menjadi beberapa kelompok kecil yang berisi 3 orang siswa/kelompok, kemudian guru membagikan storybord yang masing-masing kelompok berbeda pokok dan tema pelajaran, pada pertemuan awal guru tidak menggunakan aplikasi "dikomikin saja" dalam proses belajar, guru menggunakan gambar sosok pahlawan sebagai media pembelajaran serta menggunkan model belajar klasikal.

Dalam proses belajar di tanggal 13 April 2018 guru mengunakan media pembelajaran "dikomikin saja" siswa dengan antusias membuat Komik pembelajaran sejarah yang disesuaikan dengan storyboard yang sudah diberikan oleh guru menggunkan aplikasi "dikomikin saja" siswa masih berkerja dalam kelompok yang telah dibagi oleh guru dengan mempertimbangkan unsur 


\author{
"Dikomikin Saja" \\ Digitalisasi Komik Pembelajaran Sejarah Perjuangan Bangsa Berbasis Android
}

heterogenitas, guru mengobservasi keaktifan siswa dalam preses pembelajaran tersebut, serta memberikan arahan serta pertimbangan dalam pembuatan komik digital tersebut.

Pada pertemuan berikutnya tanggal 20 April 2018 setiap kelompok yang telah menyelesaikan penugasan pembuatan komik tersebut siswa mempresentasikan komik yang mereka telah buat, serta membagikan hasil presentasi hasil kerja kelompok kepada kelompok lain, pada saat presentasi ini kelompok lain diperbolehkan saling mengkritisi dan menanyakan hasil karya kelompok lain serta memberikan saran perbaikan, posisi guru hanya sebagai regulator dalam kegiatan presentasi tersebut. Setelah seluruh kelompok mempresentasikan hasil kerja merek serta memperbaiki hasil kerja kelompok mereka, kelompok kepada kelompok lain, pada saat presentasi ini kelompok lain diperbolehkan saling mengkritisi dan menanyakan hasil karya kelompok lain serta memberikan saran perbaikan, posisi guru hanya sebagai regulator dalam kegiatan presentasi tersebut. Setelah seluruh kelompok mempresentasikan hasil kerja merek serta memperbaiki hasil kerja kelompok mereka

Pada akhir pembelajaran, pertemuan awal, I, dan II, guru memberikan soal untuk melihat ketuntasan belajar pada bahasan tersebut dan menutup kegiatan tersebut dengan mereview kembali garis-garis besar pokok bahasan tersebut.

Dari proses pembelajaran diatas dapat dilihat bahwa pengunaan aplikasi ini memiliki nilai kebermanfaatan sebagai berikut.:

1. Memberikan gambaran yang jelas tentang bagaimana peserta didik memahami materi pelajaran yang telah disampaikan oleh guru.

2. Memberikan pengayaan bagi siswa untuk mengingat kembali materi belajar yang lalu

3. Memberikan pengalaman baru pada peserta didik untuk berinteraksi secara individu maupun kelompok

4. Peserta didik diberikan ruang yang luas untuk aktif, kreatif dan dinamis diadalam proses pembelajaran.

5. Peserta didik diberikan hak dan kebebasan yang sama dalam berkreasi serta menunjukan kemampuan secara individu maupun kelompok . 
6. Peserta didik diajak untuk berpindah dari Comfort Zone pembelajaran yang selama ini terjadi pada proses belajar

7. Peserta didik diajak untuk lebih akrab terhadap produk produk tekhnologi serta informasi yang dapat digunkana untuk proses pembelajaran serta memakainya secara positif

8. Guru dan Peserta didik diajak untuk secara maksimal menciptakan konsep dan media pembelajaran yang berbasis dari teknologi yang berkembang saat ini

\section{HASIL DAN PEMBAHASAN}

Berdasar hasil pengolahan data kuantiatif dari tes pembelajaran serta observasi selama 3 (tiga) pertemuan/siklus dapat dianalisis sebagai berikut:

1. Hasil belajar 35 siswa terlihat mengalami peningkatan, pada pertemuan awal siswa yang tuntas sebesar 40,54 \%, sedangkan pada pertemuan I dan II terjadi perubahan dimana kenaikan jumlah siswa yang tuntas belajar yaitu 55,45\% dan 68,08\%, angka angka tersebut didapat dari nilai siswa menjawab soal tes hasil belajar yang dilaksanakan dalam setiap akhir pertemuan:

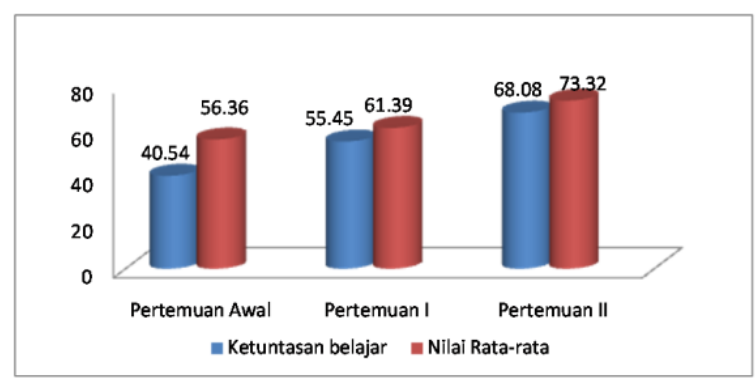

Gambar. 3 Hasil Belajar Dan Nilai Rata Rata Siswa

Keaktifan siswa dalam proses pembelajaran hasil observasi menunjukan peningkatan dalam setiap obeservasi, pada masa Pertemuan Awal skor keaktifan siswa adalah 2,13 masuk kedalam kriteria cukup dan meningkat dan terus meningkat pada pertemuan I sebesar 2,75 dengan kriteria baik serta 3,25 pada Pertemuan II dengan kriteria sangat baik, dilihat dari aktivitas siswa dalam pembelajaran, siswa lebih aktif, kreatif dalam berpikir lebih berkonsentrasi serta dinamika kelompok juga berjalan ketika mereka bekerja secara kelompok. 


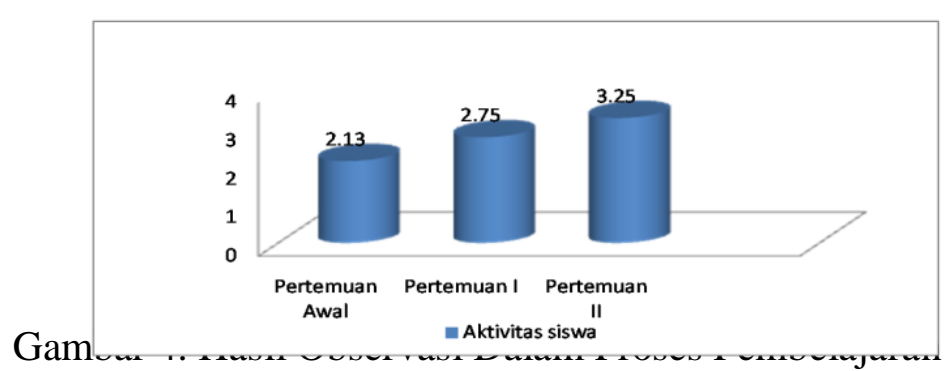

\section{SIMPULAN}

"Dikomikin saja" peneliti yakini mampu meningkatkan keterlibatan aktivitas siswa dalam proses belajar yang berujung pada meningkatnya ketuntasan belajar para siswa, fakta tersebut dibuktikan dengan hasil belajar para siswa yang Nilai rata ratanya 70,32 atau 81,08\% dari 35 siswa telah tuntas.

Serta naiknya aktivitas siswa dalam proses belajar ditunjukan dengan skor aktivitas siswa sebesar 32,5, hal ini mencermikan penterlibatan siswa sebagai subjek pembelajaran tercapai melalui penggunaan media pembelajaran "Dikomikin saja".

Aplikasi "Dikomikin saja" praktis dan sangat mudah, karena aplikasi ini dapat dikerjakan seperti orang bermain saja dan sebagaian besar siswa sudah sangat familiar dengan aplikasi android.

Dengan media pembelajaran "Dikomikin saja" siswa lebih aktif belajar, kreatif dalam berpikir, semangat dan termotivasi untuk belajar IPS, serta kemampuan mengerjakan soal IPS juga meningkat.

\section{REFERENSI}

Arsyad,Azhar. 2010.Media Pembelajaran,Jakarta,Rajawali PressDaryanto. 2009. Panduan Proses Pembelajaran Kreatif \& Inovatif. Publisher.Jakarta:

Hasan,Hamid 2012. Pendidikan Sejarah Indonesia: Isu Dalam Ide Pembelajaran,Bandung: Rizqi Press

Hermawati,Tety.2015.Komik Digital Untuk Pembelajaran Yang Menyenangkan: Jakarta.Aura Publihsing 
Kasmadi,Hartono.2001. Pengembangan Pembelajaran dengan Pendekatan Model-model Pengajaran Sejarah.Semarang: Prima Nugraha Nugraha Prtama

Kemendikbud. 2006. Permendikbud Nomor 22 Tahun 2006 Tentang Standar Isi. Jakarta: Kementerian Pendidikan dan Kebudayaan RI

Kochhar, S.K. 2008. Pembelajaran Sejarah. Penerjemah Purwanta dan Yofita Hardiwati. Jakarta: Grasindo.

Masdiono,Toni 2010.14 Jurus Membuat Komik .Jakarta: Creative Media

Nahatanael,Daldjoeni.2008.Geogarfi Sejarah.Bandung: Penerbit Alumni

Sadiman,Arief dkk. 2012. Media Pendidikan Pengertian, Pengembangan dan Pemanfaatannya, Jakarta : Raja Grafindo Persada.

Sadulloh,Uyoh 2012, pengantar Filsafat Pendidikan,Jakarta: Alfabeta

Sudjana, Nana dan Ahmad Rivai.2009. Media Pengajaran. Bandung: Sinar Baru Algesindo 